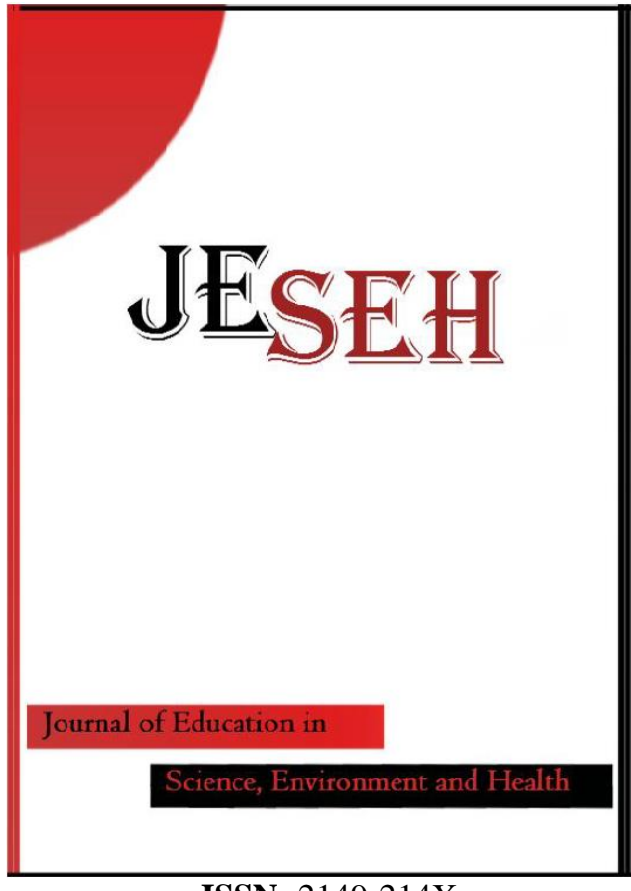

ISSN: $2149-214 \mathrm{X}$
Journal of Education in Science, Environment and Health

www.jeseh.net

How Do Prospective Elementary and Gifted Education Teachers Perceive Scientists and Distinguish Science from Pseudoscience?

Sezen Camci Erdogan

Istanbul University-Cerrahpasa

To cite this article:

Camci-Erdogan, S. (2019). How do prospective elementary and gifted education teachers perceive scientists and distinguish science from pseudoscience? Journal of Education in Science, Environment and Health (JESEH), 5(1), 119-133. DOI:10.21891/jeseh.487304

This article may be used for research, teaching, and private study purposes.

Any substantial or systematic reproduction, redistribution, reselling, loan, sub-licensing, systematic supply, or distribution in any form to anyone is expressly forbidden.

Authors alone are responsible for the contents of their articles. The journal owns the copyright of the articles.

The publisher shall not be liable for any loss, actions, claims, proceedings, demand, or costs or damages whatsoever or howsoever caused arising directly or indirectly in connection with or arising out of the use of the research material. 


\title{
How Do Prospective Elementary and Gifted Education Teachers Perceive Scientists and Distinguish Science from Pseudoscience?
}

\author{
Sezen Camci Erdogan
}

\begin{tabular}{|c|c|}
\hline Article Info & Abstract \\
\hline Article History & $\begin{array}{l}\text { The present study aims to examine the perceptions towards scientists and } \\
\text { science/pseudoscience distinctions of gifted education and elementary }\end{array}$ \\
\hline Received: & education teacher candidates who will educate gifted students especially at the \\
\hline 12 March 2018 & elementary education level. A total of 92 volunteer prospective teachers, \\
\hline Acce & composed of candidates from gifted education and elementary education \\
\hline $27 \mathrm{Jul}$ & $\begin{array}{l}\text { departments, participated in the study, which was carried out as a survey } \\
\text { research. The data were collected using the Draw-a-Scientist Test and the }\end{array}$ \\
\hline Keywords & $\begin{array}{l}\text { Science/Pseudoscience Distinction Scale. The results of the study showed that } \\
\text { both groups of prospective teachers' crafted drawings that reflected }\end{array}$ \\
\hline $\begin{array}{l}\text { Prospective teachers of } \\
\text { gifted }\end{array}$ & $\begin{array}{l}\text { stereotypical perceptions in terms of appearance, work carried out by } \\
\text { scientists, and gender. However, according to the results of the independent }\end{array}$ \\
\hline $\begin{array}{l}\text { Science-pseudoscience } \\
\text { distinction }\end{array}$ & $\begin{array}{l}\text { samples t-test, the elementary education teacher candidates were found to } \\
\text { reflect more stereotypical characteristics in their drawings of scientists than }\end{array}$ \\
\hline Images of scientists & $\begin{array}{l}\text { the gifted education teacher candidates. The candidates' } \\
\text { science/pseudoscience distinction scores did not significantly differ in } \\
\text { department and there was a negative significant correlation between } \\
\text { stereotypical image scores and scientific method scores. }\end{array}$ \\
\hline
\end{tabular}

\section{Introduction}

Today, the speed and ways of access to information is increasing. This process confronts us with many inventions and technologies that we have seen in science fiction films in the past and thought how they could be possible. While it is such a rapid process with many alternative ways to reach information, the extent to which the accessed information is scientific has become a situation which should definitely be considered. Because, today, when developments and applications such as the use of nanotechnology, the possibility of human cloning and migration to space are carried over to our daily lives, there are still also people who regulate their day or what they do or do not do according to astrological interpretations, rely on news about UFOs and reincarnation. That is why the production and use of scientific knowledge should be a responsibility not only to the scientists who have committed themselves to science but also to all the members of society. With this understanding, many countries have emphasized the importance of scientific literacy with educational reforms in order to enable the society to develop a correct and effective scientific understanding and apply it (Turgut, 2007). Therefore, in the current educational understanding, what is expected of people to do is not only to learn scientific facts, theories or laws but also to appreciate the value, power, characteristics and limits of scientific knowledge (Turgut, Akçay and İrez, 2010), and, at some point, to be able correctly grasp the nature of science.

Scientific literacy education is, especially, among the objectives to be achieved in science education in the Turkish system (MEB, 2013), but should not be limited to science education alone. In the education of scientifically literate individuals, whatever the sub-domain of science it is that is being taught, the essential point is that the nature of science should be grasped correctly (Lederman, 2007). The nature of science tries to explain what science is, how it works, how scientists work, how the society is guiding scientific knowledge and practices, and how the society reacts to these scientific applications (A ğlarcı and Kabapınar, 2016). One of the important characteristics of scientific literacy is to distinguish between science and pseudoscience as well as knowing the sub-dimensions of science and being scientific (Norris and Philips 2003; Lederman, 2007). The basic knowledge and perceptions about the nature and nature of science are dynamic, and their knowledge and perceptions change as they develop (Suchting, 1995).

In the process of separating the scientific from the non-scientific, it is necessary to define what science is. At this point, philosophers such as Popper, Kuhn and Feyeraband try to define science and make boundaires fot it but they differed on some issues like scientific process and validity criterions. These differentiations have become one of the major problem areas, especially since the early twentieth century, because they led to uncertainty 
about criterions on the separation of science from non-scientific areas (Mahner, 2007). It is still a matter of debate that there may be criteria for deciding what is scientific (Eş and Turgut, 2018). In this point, it is important that the demarcation of scientific and pseudoscientific knowledge is carried out; but an open, indisputable series of criteria that can be applied in any case for a definite demarcation has not yet been established (Turgut, 2011). However, it can be acted on some criteria suggested by different philosophical movements philosophers (Çetinkaya, Turgut and Duru, 2015). The falsifiability of scientific knowledge, its subjectivity, its inclusion of imagination and creativity for the benefit of people, its being a combination of observations and inferences, and its being influenced by social and cultural contexts can be regarded as the accepted criteria in assessing whether any emerging information is scientific or not (Lederman, 1999; Abd-ElKhalick and Lederman, 2000). In order for a solution to a problem to be scientific, it must be logical, correct, and depend on reliable observations and experiments. None of the forms of non-scientific solutions meet these three conditions. The disciplines that do not meet all of these conditions but bear one or two are defined as pseudoscience (Yildırım, 2010). These disciplines are claimed to be scientific but are thoughts that cannot experimentally be tested (Preece and Baxter, 2000).

In order to overcome difficulties in demarcation, in Smith and Sharmann (1999)' approach, the question "What are the features that do or do not make a field more scientific ?" is seen as basic problem rather than the question of "Is this scientific or not ?" and a field revealed is judged by whether it is more scientific or less scientific. According to Smith and Sharmann (1999 the characteristics that make an field more scientific are "The object and Process of Study" and "Values of Science"; the characteristics that make a field less scientific are "Espousing a Theological Position", "Valuing Authority over Evidence "and" Fideism". When we look at the approaches in the literature, it can be said that this approach is better suited then giving certain lines for scientific or non-scientific (Eş and Turgut, 2018). Every day there are lots of news about information that is claimed to be scientific through the Internet, newspapers or televisions. Many individuals who cannot distinguish between science and pseudoscience easily make mistakes and suffer material and spiritual harm. For this reason, in particular, some criteria are needed to decide whether this information is scientific or pseudoscientific. Accordingly, as the number of scientifically literate individuals in the society increases, it will not be wrong to say that the views of the community towards science will improve (Driver et al., 1996).

One of the important influences in improving the scientific literacy levels of individuals in society is the proper settlement of perceptions about scientists, their characteristics, how they work and who can do science. The interest in and perceptions about science and scientists are very important in making scientific knowledge more accessible (Camci-Erdogan, 2018). Considering that the bases of the first science experiences of individuals are established in the elementary education, teachers' attitudes and the learning environment they prepare are influential on the interest, attitudes and performances of elementary school students towards science and scientists (Carnes 2009; Christidou 2011; She and Fisher, 2002; Sönmez, 2007, Washton, 1971). However, students who develop negative attitudes toward science and scientists do not see scientific subjects as interesting and do not want to choose a course or profession related to science in the future (Hammrich, 1997; Milford and Tippet, 2013).

Gifted students have an inherent interest in scientific subjects because such subjects nurture their instinctual curiosity and motivation (SmutnyVon and Fremd, 2004). They have the ability to transfer inferences from different events and situations to unusual situations in everyday life (Kopelman, Galasso and Strom, 1977; Ngoi and Vodracek, 2004). They achieve such inferences through scientific processes by closely observing their environments (Karnes and Riley, 2005), by recognizing and identifying the problems that others have missed (Meador, 2003), and by enjoying the exploration of open-ended problem situations. They have a passion including motivation, insistence, discovery skills and natural ability towards scientific subjects. It can be said that these students with characteristics such as being highly interested in exploring scientific events, being inclined to observe and ask questions, and having a deep interest in any discipline of science (Cooper, Baum and Neu, 2004, 2005; Taber, 2007) are the individuals who have a prominent role in the production of scientific knowledge or in its effective use. Accordingly, it would not be wrong to say that giving precedence to the education of gifted students is one of the most valuable investments that a society can make towards its future. Teachers who will educate gifted students should be at a level that can support and push forward such motivation, desires and interests of the students, because elementary teachers are one of the primary sources of information for science and scientists, and the influence they have on their students cannot be denied (Matthews and Davies, 1996; Christidou 2011; Moseley and Norris, 1999).

At the level of elementary education, students get introduced to subjects like science, scientific knowledge, and scientists in the formal sense or improve their knowledge on such knowledge areas with the help of their teachers (Turgut et al., 2016). In our current education system, a gifted student is educated at the elementary level either 
by an elementary teacher or by a gifted education teacher who has been appointed as an elementary teacher. At this point, the perception, attitudes and beliefs that the prospective teachers of elementary education and gifted education - who are more likely to work with gifted students in the first stages of elementary education - have towards science and scientists are very important.

It should be among the targets of teacher education institutions to know the views of prospective teachers who will educate future scientifically literate individuals about scientists and scientific/non-scientific activities and to try to overcome their misconceptions about these issues (Ağlarc1 and Kabapınar, 2016). The reason is that teacher candidates' views on science and science subjects are based on their experiences in their own school years. Their views are very rooted and resistant to change (Hewson and Hewson, 1989). Since the study of Mead and Metraux (1957) on high school students' perceptions towards scientists, many studies have been carried out on different groups. Studies were carried out on such as elementary students (Buldu, 2006; Kaya, Doğan and Öcal, 2008; Türkmen, 2008), elementary and secondary students as a comparison (Akcay, 2011; Fung, 2002, secondary students (Camci, 2008; Gonsoulin 2001; Song and Kim, 1999), secondary gifted students (CamciErdogan, 2013a, 2013b; Kemaneci, 2012; Turgut, Öztürk and Eş, 2017). Based on these studies carried out with students it has been revealed that participants mostly have a stereotypical perception towards scientists whom they perceived as a middle-aged, lonely male wearing a laboratory coat and glasses and experimenting in a laboratory. Studies in the literature are mostly concerned with the students but also some studies conducted with the teacher candidates. These studies are mostly conducted with elementary teacher candidates (Çermik, 2013; Reap, Cavallo and McWhirter, 1994; Ünver, 2010), mixed groups (science, social studies, elementary, music etc.) (Bozdoğan, Şengül and Bozdoğan, 2013; Moseley and Norris, 1999; Özkan et al.,2017; Ürey et al., 2017). When looking at the results of available research, similar to the work done by the students in the studies conducted with the prospective teachers, it has been revealed that mostly the teacher candidates have stereotypical image of scientists as middle aged lonely men working with laboratory materials in a closed environment. As a result of these studies, stereotypes for scientists are formed at the level of elementary education and continue for many years or even for life. So it is important to determine image of elementary teachers of gifted students who have are thought to play an important role because of their potential. But researcher had reached only one study conducted with gifted education teacher candidates (Camci-Erdogan, 2018) who will give the initial guidance and effect in the academic and scientific life of gifted students.

Considering the studies focusing on the distinction between science and pseudoscience, many studies have been carried out on teacher candidates (Ağlarcı and Kabapınar, 2016; Ayvacı and Bağ, 2016; Berkant and Ermeydan, 2017; Çetinkaya, Laçin-Şimşek and Çalışkan, 2013; Kallery, 2001; Losh and Nzekwe, 2011; Saka and Sürmeli, 2017; Şenler and İrven, 2016; Turgut, 2009; Turgut et al., 2016; Yates and Chandler, 2000) and teachers (Berkman, Pacheco and Plutzer, 2008; Eve and Dunn, 1990; Nehm and Schonfeld, 2007). It is seen that in our country, Turkey, studies focusing on the distinction between science and pseudoscience mostly have included prospective science teachers (Ağlarcı and Kabapınar, 2016; Çetinkaya, Laçin-Şimşek and Çalışkan, 2013; Saka and Sürmeli, 2017; Turgut, 2009; Turgut, 2011; Turgut, Akçay and İrez, 2010) who are regarded as the most important and responsible individuals for raising scientifically literate individuals. The task prospective science teachers have in terms of raising scientifically literate individuals is obvious. However, in the framework of formal education - especially at the elementary education level — the first teachers the students will work with to study scientific literacy will be the elementary school teachers. The first teachers the gifted students will work with in the same manner will be the gifted education teachers. Gifted students share their first official science practice with elementary education and gifted education teachers. For this reason, the role of elementary and gifted education teachers is crucial as the first step in scientific literacy, scientific skills and in general science education (Akerson, Buzzelli \& Donely, 2010). So the aim of the present study is therefore to determine the perceptions towards scientists and science/pseudoscience distinctions of gifted and elementary education teacher candidates who will give education to gifted students at the elementary level and guide them to the exploration, use and production of scientific knowledge. For this purpose, research problems are as follows:

1. What are images of scientists of candidate elementary education and candidate gifted education teachers according to departments?

2. Do teacher candidates differ in stereotypical image scores of scientists according to department?

3. Do teacher candidates differ in science/pseudoscience distinction scores according to department?

4. What are images of scientists of candidate elementary education and candidate gifted education teachers according to genders in department?

5. Do teacher candidates' stereotypical image mean scores differ according to gender in departments?

6. Do teacher candidates' science/pseudoscience distinction mean scores differ according to gender in departments? 
7. Is there any correlation between stereotypical image scores and science/pseudoscience distinction scores?

\section{Method}

\section{Design of the Study}

This study was carried out as a survey research with the aim of determining science/pseudoscience distinction levels of prospective teachers of elementary and gifted education and their perceptions towards scientists.

\section{Participants}

The sample of the study consisted of 92 teacher candidates who were studying in 4th (last) grade of the Gifted Education and Elementary Education undergraduate departments at a state university located in Istanbul in the academic year of 2016-2017. The convenience sampling method, one of the purposive sampling methods (Creswell, 2012; Y1ldırım and Şimşek, 2008), was adopted when determining the sample. The participant was given information about the subject of study by the researcher in separate groups as elementary and gifted education department. Participants voluntarily participated in the study. Seven students were excluded from the study because they did not have drawings for scientists and they responded some items multiple times on likert type scales. The department and gender distribution of the candidates participating in the study is given in Table 1. Table 1 shows that there were $43(86 \%)$ female and $7(14 \%)$ male participants from the elementary education department, and $30(85.7 \%)$ female and $5(14.3 \%)$ male participants from the gifted education department.

Table 1. Frequency and percentages according to department and gender

\begin{tabular}{llll}
\hline Department & Gender & $\mathrm{f}$ & $\%$ \\
\hline Elementary & Male & 7 & 14 \\
Education & Female & 43 & 86 \\
& Total & 50 & 100 \\
\multirow{3}{*}{ Gifted Education } & Male & 5 & 14.3 \\
& Female & 30 & 85.7 \\
& Total & 35 & 100 \\
\hline
\end{tabular}

\section{Data Collection Tools}

\section{Draw-a-Scientist Test (DAST)}

The Draw-a-Scientist Test (DAST) (Chambers, 1987) was used to determine the data for the perceptions towards the scientists in the study. This was a test that allowed people to draw pictures to explain their thoughts about scientists. In this test, the students were given the following instruction: "Please close your eyes and imagine a scientist working. Open your eyes and draw the scientist you imagined." Underneath the blank area for drawing was a field for the students to mark the age and gender of the scientist. Drawing ideas and perceptions towards scientists is an advantage for DAST in terms of allowing participants to express their own ideas freely and to facilitate its implementation (Öcal, 2007).

\section{Science/Pseudoscience Distinction Scale}

The Science/Pseudoscience Distinction Scale was used in obtaining science and pseudoscience distinction scores of the teacher candidates. The original of the scale was developed by Oothoudt (2008) and adapted to Turkish by Çetinkaya, Laçin-Simşek and Çalışkan (2013). The scale consisting of 23 Likert-type items had four subdimensions as "Pseudoscience, Scientific Method, Science/Pseudoscience Distinction and Pseudoscientific Beliefs." The Cronbach-alpha coefficient of the adapted scale had been found to be .75 as a result of the reliability analysis, while its Cronbach-alpha coefficient of scale was .73 and four sub-dimensions as Pseudoscience, Scientific Method, Science/Pseudoscience Distinction and Pseudoscientific Beliefs were successively $.75, .71, .69$ and .68 in the present study. 


\section{Data Collection and Analysis}

The two scales were applied together to the volunteer teacher candidates. In the analysis of teacher candidates' drawings regarding scientists, the Draw-a-Scientist Checklist (DAST-C) developed by Finson, Beaver and Cramond (1995) was used. When the variables were coded, the expressions that reflected stereotypes in perception towards scientists were coded as 1 , and their absence was coded as 0 . The stereotypes towards scientists were coded as follows:

1. Laboratory Coat: In the drawings of teacher candidates, if the scientist wore a lab coat, this was coded 1 . If the scientist was not wearing one, it was coded 0 .

2. Glasses: This was coded 1 , if the scientist was wearing eyeglasses. It was coded 0 , if the scientist was not wearing them.

3. Beard/Mustache: If the scientist was wearing any combination of beard, mustache or sideburns, this was coded 1 . If not, it was coded 0 .

4. Messy-looking: If the scientist was messy-lookin, it was code 1 . If not, it was code 0.

5. Research Symbols: If there was a beaker, volumetric flask, lame/lamella, solution, or any similar laboratory equipment in the drawings, this was coded 1 . If there was no laboratory equipment, it was coded 0 .

6. Information Symbols: If there were symbols in the drawings, such as a book, file, pen, or note, this was coded 1 . If there were no symbols, it was coded 0.

7. Technology Symbols: The presence of any technological objects such as a television, telephone, robot, computer, microscope, or telescope was coded as 1 . Their absence was coded as 0 .

8. Gender: If the scientist was male, this was coded 1. If the scientist was female, it was coded 0.

9. Lonely Working: If the scientist was working alone, it was code 1 . If not, it was coded 0.

10. Working Environment: If the scientist was working in a closed interior (such as a laboratory or library), this was coded 1 . If the scientist was working outside, it was coded 0.

11. Age of the Scientist: If the scientist's age was expressed as 40 or more, this was coded 1. If it was expressed as 39 or below, it was coded 0 .

The increase in the scores received by the prospective teachers indicates that they reflected more stereotypical characteristics in their drawings. In the study, two experienced experts evaluated $10 \%$ of the number of participants (10 participants) together during the evaluation of scientist drawings. Experts shared their decisions with each other after they have completed coding individually. Each of them declared their ideas on codes that are not consensus. They convince each other through this idea sharing and then they negotiated the codes on which they did not agree to come up with the final codes. The Science/Pseudoscience Distinction scale was applied in collectively to both groups and given as long as participants wished to participate. Since the collected data was likert type, it was coded 1 for "I strongly do not agree", 2 for "I do not agree", 3 for "I am undecided", 4 for "I agree" and 5 for "I strongly agree". Reverse encoded items are corrected. In addition, skewness and kurtosis coefficients were checked based on the analyses to examine whether the data were normally distributed. The skewness and kurtosis coefficients calculated for the stereotypical scientist perception score were .648 and .845 , and for the Science/Pseudoscience Distinction score, .454 and .021 , respectively. According to these results, frequency, percentage, independent samples t-test and correlational analysis were used in the analysis of the data showing normal distribution.

\section{Results}

1. What are images of scientists of candidate elementary education and candidate gifted education teachers according to departments?

Table 2 shows that almost half $(44 \%)$ of the prospective elementary teachers described a scientist with a laboratory coat, while $14.3 \%$ of the prospective gifted education teachers described a scientist with a laboratory coat. Both elementary education and gifted education teacher candidates drew scientists with an almost $50 \%$ messy-looking image. $88 \%$ of elementary education teacher candidates portrayed the scientist with research symbols such as a beaker, volumetric flask and test tube, while $40 \%$ of prospective teachers of gifted education used these symbols. Symbols such as books and desktop notes were used at $50 \%$ level in both groups. While more than $50 \%$ of elementary education teacher candidates described the scientist as a male, more than $50 \%$ of the prospective teachers of gifted education described the scientist as a female. A great majority of both groups drew scientists as a person working alone (100\% and $85.7 \%$, respectively) indoor (90\% and $74.3 \%$, 
respectively). More than half of the teacher candidates in both groups portrayed that the scientist was 10 to 39 years old.

Table 2. Frequency and percentages of stereotypes according to department

\begin{tabular}{lcccc}
\hline & \multicolumn{2}{c}{ Elementary Education } & \multicolumn{2}{c}{ Gifted Education } \\
Codes & $\mathrm{f}$ & $\%$ & $\mathrm{f}$ & $\%$ \\
\hline Laboratory Coat & 22 & 44 & 5 & 14.3 \\
Glasses & 20 & 40 & 8 & 22.9 \\
Beard/Mustache: & 6 & 12 & 2 & 5.7 \\
Messy-looking & 25 & 50 & 17 & 48.6 \\
Research Symbols & 44 & 88 & 14 & 40 \\
Information Symbols & 24 & 48 & 19 & 54.3 \\
Technology Symbols & 5 & 10 & 14 & 40 \\
Male & 30 & 60 & 13 & 37.1 \\
Female* & 19 & 38 & 19 & 54.3 \\
Lonely Working & 50 & 100 & 3 & 85.7 \\
Working Inside & 45 & 90 & 26 & 74.3 \\
At the age of 40 and up & 21 & 42 & 11 & 31.4 \\
\hline
\end{tabular}

* Even though the code of female image was not on the markers as a stereotype, it was included in the table because it was an important finding for study.

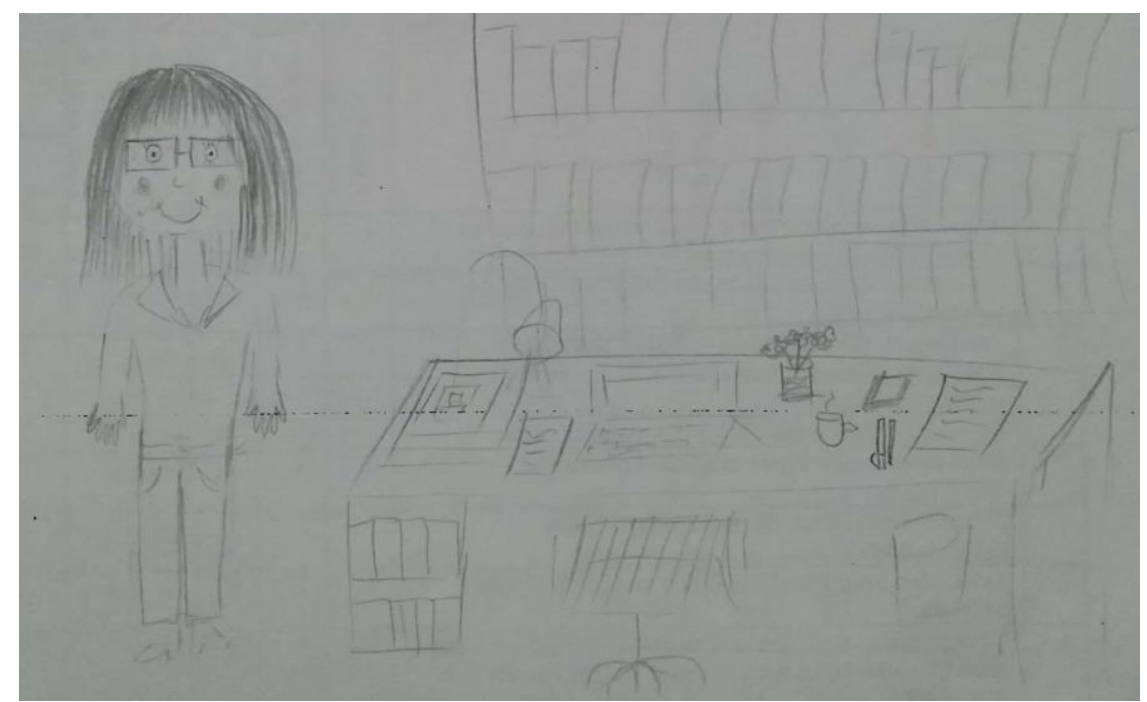

Figure 1. Sample image belongs to a gifted education teacher candidate

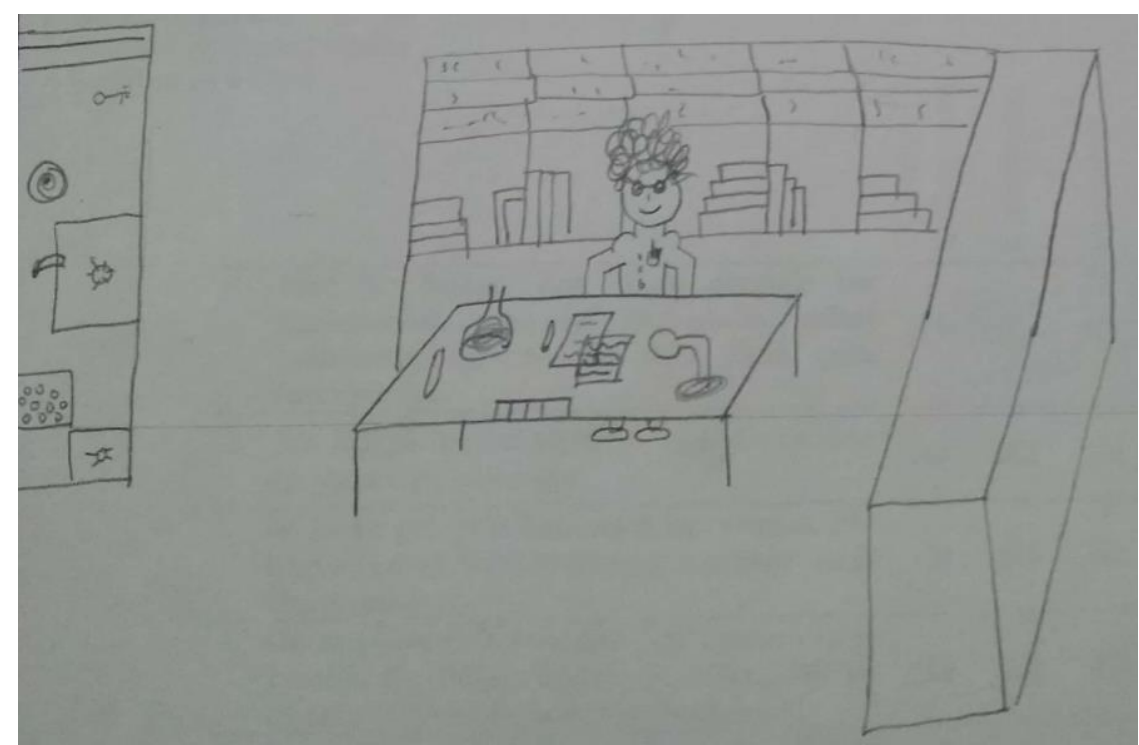

Figure 2. Sample image belongs to a elementary education teacher candidate 


\section{Do teacher candidates differ in stereotypical perception scores of scientists according to department?}

Table 3 shows that the stereotypical perception scores of the prospective teachers had a statistically significant difference in terms of the department in which they studied $(t=2.76, \mathrm{p}<.05)$. At this point, it was revealed that the teacher candidates who were studying in the department of elementary education had more stereotypical images in terms of perception towards scientists than those who studied in the department of gifted education.

Table 3. Independent t test analysis for images: Department

\begin{tabular}{llllllll}
\hline & Department & $\mathrm{N}$ & Mean & $\begin{array}{l}\text { Std. } \\
\text { Deviation }\end{array}$ & $\mathrm{t}$ & $\mathrm{df}$ & $\mathrm{p}$ \\
\hline $\begin{array}{l}\text { Stereotypical } \\
\text { perception } \\
\text { scores }\end{array}$ & $\begin{array}{l}\text { Elementary } \\
\text { Education }\end{array}$ & 50 & 6 & 2.109 & & & \\
\hline
\end{tabular}

$* \mathrm{p}<0.05$ There was a significant difference.

\section{Do teacher candidates differ in science/pseudoscience distinction scores according to department?}

Table 4 shows that the scores obtained from the science/pseudoscience distinction scale of the prospective teachers of elementary education and gifted education did not differ significantly based on their departments, neither in any of the sub-scales — specifically, pseudoscience $(\mathrm{t}=.201, \mathrm{p}>.05)$, scientific method $(\mathrm{t}=-1.162$, $\mathrm{p}>.05)$, science/pseudoscience distinction $(\mathrm{t}=1.318, \mathrm{p}>.05)$, pseudoscientific beliefs $(\mathrm{t}=-.327, \mathrm{p}>.05)$ - nor in the whole of the scale $(\mathrm{t}=.115, \mathrm{p}>.05)$.

The mean scores of the teacher candidates taken from the sub-dimensions and the overall scale were evaluated according to their average weight values. The ranges in the 5-point Likert type scale were determined to be 1.01.8, 1.9-2.6, 2.7-3.4, 3.5-4.2 and 4.3-5.0 for "Very Low," "Low," "No Idea," "High" and "Very High," respectively (Ayvacı and Bağ, 2016). The average scores of the gifted education and elementary education teacher candidates show that both groups were in the level of "No idea" in terms of the pseudoscience and pseudoscientific beliefs sub-dimension. The scores of the groups in the scientific method and science/pseudoscience distinction sub-dimensions and in the whole scale were all "High."

Table 4. Independent $\mathrm{t}$ test analysis for science/pseudoscience distinction: Department

\begin{tabular}{|c|c|c|c|c|c|c|c|}
\hline $\begin{array}{l}\text { Science/pseudoscience } \\
\text { distinction scale scores }\end{array}$ & Department & $\mathrm{N}$ & Mean & $\begin{array}{l}\text { Std. } \\
\text { Deviation }\end{array}$ & $\mathrm{t}$ & df & $\mathrm{p}$ \\
\hline \multirow{2}{*}{ Pseudoscience } & $\begin{array}{l}\text { Elementary } \\
\text { Education }\end{array}$ & 50 & 3.04 & .387 & \multirow{2}{*}{.210} & \multirow{2}{*}{90} & \multirow{2}{*}{.834} \\
\hline & $\begin{array}{l}\text { Gifted } \\
\text { Education }\end{array}$ & 35 & 3.02 & .508 & & & \\
\hline \multirow{2}{*}{ Scientific method } & $\begin{array}{l}\text { Elementary } \\
\text { Education }\end{array}$ & 50 & 3.93 & .415 & \multirow{2}{*}{-1.162} & \multirow{2}{*}{90} & \multirow{2}{*}{.248} \\
\hline & $\begin{array}{l}\text { Gifted } \\
\text { Education }\end{array}$ & 35 & 4.03 & .332 & & & \\
\hline \multirow{2}{*}{$\begin{array}{l}\text { Science/pseudoscience } \\
\text { distinction }\end{array}$} & $\begin{array}{l}\text { Elementary } \\
\text { Education }\end{array}$ & 50 & 4.05 & .465 & \multirow{2}{*}{1.318} & \multirow{2}{*}{90} & \multirow{2}{*}{.191} \\
\hline & $\begin{array}{l}\text { Gifted } \\
\text { Education }\end{array}$ & 35 & 3.91 & .539 & & & \\
\hline \multirow[t]{2}{*}{ Pseudoscientific beliefs } & $\begin{array}{l}\text { Elementary } \\
\text { Education }\end{array}$ & 50 & 3.23 & .608 & \multirow[t]{2}{*}{-.327} & \multirow[t]{2}{*}{90} & \multirow[t]{2}{*}{.745} \\
\hline & $\begin{array}{l}\text { Gifted } \\
\text { Education }\end{array}$ & 35 & 3.28 & .798 & & & \\
\hline \multirow{2}{*}{ Whole of the scale } & $\begin{array}{l}\text { Elementary } \\
\text { Education }\end{array}$ & 50 & 3.60 & .266 & \multirow{2}{*}{.115} & \multirow{2}{*}{90} & \multirow{2}{*}{.909} \\
\hline & $\begin{array}{l}\text { Gifted } \\
\text { Education }\end{array}$ & 35 & 3.59 & .303 & & & \\
\hline
\end{tabular}


4. What are images of scientists of candidate elementary education and candidate gifted education teachers according to genders in department?

The percentages, frequencies and averages of scores were compared in gender comparisons rather than independent sample $t$ test because of the difference in the distribution between male and female students.

Table 5. Frequency and percentages of stereotypes according to gender in departments

\begin{tabular}{|c|c|c|c|c|c|c|c|c|}
\hline \multirow{3}{*}{ Codes } & \multicolumn{4}{|c|}{ Gifted Education } & \multicolumn{4}{|c|}{ Elementary Education } \\
\hline & \multicolumn{2}{|c|}{ Male } & \multicolumn{2}{|c|}{ Female } & \multicolumn{2}{|c|}{ Male } & \multicolumn{2}{|c|}{ Female } \\
\hline & $\mathrm{f}$ & $\%$ & $f$ & $\%$ & $\mathrm{f}$ & $\%$ & $\mathrm{f}$ & $\%$ \\
\hline Laboratory Coat & 1 & 20 & 4 & 13.3 & 1 & 14.3 & 21 & 48.8 \\
\hline Glasses & 2 & 40 & 6 & 20 & 3 & 42.9 & 17 & 39.5 \\
\hline Beard/Mustache & 0 & 0 & 2 & 6.7 & 1 & 14.3 & 5 & 11.6 \\
\hline Messy-looking & 4 & 80 & 13 & 43.3 & 5 & 71.4 & 20 & 46.5 \\
\hline Research Symbols & 2 & 40 & 12 & 40 & 3 & 42.9 & 41 & 95.3 \\
\hline Information Symbols & 3 & 60 & 16 & 53.3 & 1 & 14.3 & 23 & 53.5 \\
\hline Technology Symbols & 2 & 40 & 12 & 40 & 2 & 28.6 & 3 & 7 \\
\hline Male & 4 & 80 & 9 & 30 & 7 & 100 & 23 & 53.5 \\
\hline Female* & 1 & 20 & 18 & 60 & 0 & 0 & 19 & 44.2 \\
\hline Lonely Working & 5 & 100 & 25 & 83.3 & 7 & 100 & 43 & 100 \\
\hline Working Inside & 5 & 100 & 21 & 70 & 4 & 57.1 & 41 & 95.3 \\
\hline At the age of 40 and up & 3 & 60 & 8 & 26.7 & 5 & 71.4 & 16 & 37.2 \\
\hline
\end{tabular}

* Even though the code of female image was not on the markers as a stereotype, it was included in the table because it was an important finding for study.

Table 5 shows that the female teacher candidates in elementary education department drew the scientists with laboratory coat $(48.8 \%)$ and glasses $(39.5 \%)$ with a higher percentage than the female candidates of gifted education department $(13.3 \%$; 20\%, respectively). Almost all female elementary teacher candidates used research symbols in their drawings $(95.3 \%)$, while less than half of the female gifted teacher candidates $(40 \%)$ used research symbols in their drawings. From the point of view of the use of the technology symbols, it was seen that female gifted education teacher candidates reflected higher percentage than female elementary education teacher candidates.

While almost all of male teacher candidates in both groups drew male scientist, the situation in female teacher candidates is different. While $30 \%$ of the female gifted education teacher candidates drew male scientists, $60 \%$ of them drew female scientists. And $53.3 \%$ of the female elementary teacher candidates drew male scientists, $44.2 \%$ of them drew female scientists. Teacher candidates in both groups have dreamed and drew scientists working alone and indoors at high percentages. When we look at the age of the drawn scientists, it has been seen that female gifted teacher candidates have drawn scientists over 40 years with a lower percentage than female elementary teacher candidates. In other words, female gifted education teacher candidates tend to imagine scientists to be under 40 years old.

\section{Do teacher candidates' stereotypical perception mean scores differ according to gender in departments?}

Table 6 shows the results of the descriptive analysis in order to see the difference difference between the scores of stereotypical perceptions towards scientists according to the gender of candidates in departments.

Table 6. Descriptive values of stereotypical perception scores due to gender in departments

\begin{tabular}{lllccccc}
\hline & Department & Gender & $\mathrm{N}$ & Min & Max & Mean & $\begin{array}{c}\text { Std. } \\
\text { Deviation }\end{array}$ \\
\cline { 2 - 8 } Stereo & Gifted & Male & 5 & 4 & 10 & 6.40 & 2.510 \\
typical & Education & Female & 30 & 0 & 10 & 4.40 & 2.094 \\
perception & Elementary & Male & 7 & 4 & 8 & 5.57 & 1.813 \\
scores & Education & Female & 43 & 3 & 13 & 6.07 & 2.165 \\
\hline
\end{tabular}

The low level of stereotypical perception scores is interpreted as the fact that teacher candidates reflect less stereotypical images of scientists. In this context Table 6 shows that the average stereotypical perception scores 
of female gifted eduction teacher candidates $(\overline{\mathrm{x}}=4.40)$ was lower than the average stereotypical perception scores of female elementary education teacher candidates $(\overline{\mathrm{x}}=6.07)$. From the point of view of male candidates, it is seen that the average scores of elementary teacher candidates $(\bar{x}=5.57)$ are lower than those of gifted education teacher candidates $(\overline{\mathrm{x}}=6.40)$.

6. Do teacher candidates' science/pseudoscience distinction mean scores differ according to gender in departments?

Table 7 shows the descriptive values of science/pseudoscience distinction scores and the mean scores of the teacher candidates taken from the sub-dimensions and the overall scale were evaluated according to their average weight values. The ranges in the 5-point Likert type scale were determined to be 1.0-1.8, 1.9-2.6, 2.7-3.4, 3.54.2 and 4.3-5.0 for "Very Low," "Low," "No Idea," "High" and "Very High," respectively (Ayvac1 and Bağ, 2016). The average scores of the gifted education and elementary education teacher candidates show that all groups were in the level of "No idea" in terms of the pseudoscience sub-dimension. Male gifted education teacher candidates were at "High level" while all the other groups were in the level of "No idea" in terms of pseudoscientific beliefs sub-dimension. The scores of the groups in the scientific method and science/pseudoscience distinction sub-dimensions and in the whole scale were all "High."

Table 7. Descriptive variables of science/pseudoscience distinction scores due to gender in departments

\begin{tabular}{|c|c|c|c|c|c|c|c|}
\hline Department & Gender & Scale & $\mathrm{N}$ & Min & Max & Mean & $\begin{array}{c}\text { Std. } \\
\text { Deviation }\end{array}$ \\
\hline \multirow{10}{*}{$\begin{array}{l}\text { Gifted } \\
\text { Education }\end{array}$} & \multirow{5}{*}{ Male } & Pseudoscience & 5 & 2 & 4 & 3.11 & .814 \\
\hline & & Scientific method & 5 & 4 & 5 & 4.29 & .286 \\
\hline & & $\begin{array}{l}\text { Science/pseudoscience } \\
\text { distinction }\end{array}$ & 5 & 3 & 4 & 3.77 & .560 \\
\hline & & Pseudoscientific beliefs & 5 & 2 & 5 & 3.60 & 1.01 \\
\hline & & Whole of the scale & 5 & 3 & 4 & 3.70 & .219 \\
\hline & \multirow{5}{*}{ Female } & Pseudoscience & 30 & 2 & 5 & 3.00 & .458 \\
\hline & & Scientific method & 30 & 3 & 5 & 3.99 & .323 \\
\hline & & $\begin{array}{l}\text { Science/pseudoscience } \\
\text { distinction }\end{array}$ & 30 & 3 & 5 & 3.93 & .541 \\
\hline & & Pseudoscientific beliefs & 30 & 2 & 5 & 3.22 & .765 \\
\hline & & Whole of the scale & 30 & 3 & 4 & 3.57 & .314 \\
\hline \multirow{10}{*}{$\begin{array}{l}\text { Elementary } \\
\text { Education }\end{array}$} & \multirow{5}{*}{ Male } & Pseudoscience & 7 & 3 & 3 & 2.87 & .212 \\
\hline & & Scientific method & 7 & 3 & 4 & 4.04 & .486 \\
\hline & & $\begin{array}{l}\text { Science/pseudoscience } \\
\text { distinction }\end{array}$ & 7 & 4 & 5 & 4.07 & .286 \\
\hline & & Pseudoscientific beliefs & 7 & 2 & 4 & 3.10 & .630 \\
\hline & & Whole of the scale & 7 & 3 & 4 & 3.57 & .189 \\
\hline & \multirow{5}{*}{ Female } & Pseudoscience & 43 & 2 & 4 & 3.07 & .402 \\
\hline & & Scientific method & 43 & 3 & 5 & 3.92 & .428 \\
\hline & & $\begin{array}{l}\text { Science/pseudoscience } \\
\text { distinction }\end{array}$ & 43 & 3 & 5 & 4.04 & .498 \\
\hline & & Pseudoscientific beliefs & 43 & 2 & 5 & 3.25 & .600 \\
\hline & & Whole of the scale & 43 & 3 & 4 & 3.61 & .287 \\
\hline
\end{tabular}

\section{Is there any correlation between stereotypical image scores and science/pseudoscience distinction scores?}

Table 8 shows, there was a negative significant correlation between stereotypical image scores and scientific method scores $[\mathrm{r}(85)=.-.221 ; \mathrm{p}<.05)$. That means stereotypical image score increases while the scientific method score decreases. As the image of the scientist is stereotyped, the individual move away from the scientific method. 
Table 8. Correlation values between stereotypical image scores and science/pseudoscience distinction scores

\begin{tabular}{llllll}
\hline & $\begin{array}{l}\text { Whole of } \\
\text { the scale }\end{array}$ & Pseudoscience & $\begin{array}{l}\text { Scientific } \\
\text { method }\end{array}$ & $\begin{array}{l}\text { Science/pseudosci } \\
\text { ence distinction }\end{array}$ & $\begin{array}{l}\text { Pseudoscientific } \\
\text { beliefs }\end{array}$ \\
\hline $\begin{array}{l}\text { Stereotypical } \\
\text { image score }\end{array}$ & -.154 & -.081 & $-.221^{*}$ & -.074 & -.036 \\
*Correlation was significant at the .05 level. & & & \\
\hline
\end{tabular}

\section{Discussion and Conclusion}

Based on the image of scientists and the level of science/pseudoscience distinction levels of prospective teachers of gifted education and elementary education, it was revealed that the prospective teachers reflected stereotypical perceptions towards scientists in their drawings in general. In the same way as many studies in the literature (Bozdoğan, Şengül and Bozdoğan, 2013; Camci-Erdogan, 2018; Çermik, 2013; Moseley and Norris, 1999; Özkan et al. 2017; Reap, Cavallo and McWhirter, 1994; Şenel and Aslan, 2014; Ünver, 2010; Ürey et al. 2017) the teacher candidates of both gifted education and elementary education portrayed scientists mainly as a middleaged, messy-looking person wearing a laboratory coat and glasses and working alone on chemicals in the laboratory. As a result of comparison between the two groups based on the stereotypical images in the drawings of scientists, it was revealed that the teacher candidates of elementary education had more stereotypical image and perception for scientists. This may had been due to the fact that the gifted education students had to take very different courses in the teacher education program, differently from the elementary education program, and in these courses they had seen different scientists (difference in gender, age, ethnicity etc.) and different ways of thinking. It may be effective, however, to take a number of lessons on the creation and development of scientific knowledge and scientific method and to participate in different projects supported at the national level in order to guide the gifted students on their curiosity about science and scientific method. It would not be wrong to say that the teacher candidates' drawings are rooted in the belief that it is exhausting and backbreaking to do science based on the presence of messy-looking scientists wearing glasses (Camci-Erdogan, 2018; Ünver, 2010; YontarToğrol, 2000). Nevertheless, it is necessary to keep in mind that doing science is perceived as working in the laboratory alone, in isolation from society, based on the drawings portraying scientists working behind closed doors alone. Similar results have been found in previous studies and it has been emphasized that the figures of scientists used in textbooks in the Internet, visual and printed media seriously affect the formation of these images (Camci-Erdogan, 2013a, 2013b; Camci-Erdogan, 2018; Schibeci, 1986; Song and Kim, 1999; YontarToğrol, 2000).

When the teacher candidates' drawings of scientists are considered in terms of what scientists do, it turns out that a great majority of the prospective teachers of both groups bu especially female elementary teacher candidates $(95.3 \%)$ reflect scientists only as someone experimenting with chemicals in the laboratory. This leads students to not see alternatives in terms of scientific literacy with regard to how scientific knowledge is produced, ways of reaching scientific knowledge, and how scientists work, which limits the perception about scientific knowledge only to sciences.

One of the most important stereotypes for the perception towards the scientist is imaging a man. In almost all of the studies on the topic, a large part of students or teacher candidates have described the scientists as males (Buldu, 2006; Camci-Erdogan, 2013a, 2013b; Chambers, 1983; Çermik, 2013; Flick, Fort and Varney, 1989; Fung, 2002; Gonsoulin, 2001; Kaya, Doğan and Öcal, 2008; Kemaneci, 2012; Mead and Metraux, 1957; Narayan et al., 2007; Schibeci, 2006; Song and Kim, 1999; Symington and Spurling, 1990; Türkmen, 2008; Ünver, 2010; Yontar-Toğrol, 2000). In the present study, while the vast majority of the prospective female elementary education teachers drew male scientists, the majority of the prospective female gifted education teachers drew female scientists. This is particularly promising in terms of breaking the notion that doing science is specific to men, and in establishing the idea that there are and will be female scientists in all areas of science (especially in physical sciences). In particular, female gifted students have a great need for their skills to be supported by role models in terms of expressing themselves on scientific platforms and not concealing themselves (Camci-Erdogan, 2013a; Camci-Erdogan and Riga, 2016). Because gifted girls mask their potential in scientific issues and it is known as an important problem on the field (Camci-Erdogan, 2013a), Therefore, it is very important for the teacher to convey to students the perception that science can be done at an equal level in terms of both genders in society. And gifted education candidates sholud have knowledge at the point of showing correct role models to girls in scientific fields. 
When we look at the age range chosen by the prospective teachers of both gifted education and elementary education to portray a scientist in their drawings, about age, both groups portrayed scientists at 30-40 age range. It cannot be denied that science is still influenced by printed media, visual media and Internet tools in terms of confining science to an age level, which can be considered a middle age in general. At this point, it can be said that, in terms of scientific literacy, we lack the emphasis that science is for all ages, and that science can be done by everyone from birth to death. The fact that scientists were working in isolation from the society in the drawings of prospective teachers confirms the perception that science cannot be done by anyone, but only by certain people. Therefore, to properly structure scientific literacy, it must be emphasized that science can be understood and done by all.

Considering the science/pseudoscience distinction scores of both groups, it was seen that prospective teachers were undecided or had no opinion on the expressions in the sub-dimension of the pseudoscience and pseudoscientific beliefs. However, it was revealed that scores of both groups were high in the scientific method, science/pseudoscience sub-dimensions and in the whole of the scale. Teacher candidates made more precise, clear and accurate decisions on issues such as scientific method and scientific research. Candidates were undecided about the pseudoscience-related issues (e.g., "Houses are visited by the ghosts of the deceased people.") and expressed their lack of ideas. However, it is also evident that the scientific method subscale is correlated reversely to the stereotypes about scientists. At this point, it has emerged that prospective teachers who have mastered the scientific method process have less stereotypes for scientists. People believe in pseudoscientific explanations because pseudoscientific explanations are given scientific implications (Y1ldırım, 2008) and pseudoscientific explanations are easier to understand than scientific explanations (Lindeman, 1998). However, the individual who knows the formation and characteristics of scientific knowledge can distinguish and put into practice scientific thought from pseudoscientific thought (Lederman, 2007). Teacher candidates familiarize with content related to scientific methods that they receive in the Scientific Research Method course and in other courses. It can be said that such contents are effective in teaching them to make more accurate and clear decisions about scientific methods. At this point, it is understood that it is necessary to offer courses with content focusing on the nature of science and what characteristics should be considered in distinguishing scientific explanations from pseudoscientific explanations, as well as emphasizing the importance of assessing the source of information.

It is very important to make the right beginnings in the learning process, because it is difficult to change the incorrect understandings, prejudices or stereotypes. Studies conducted with gifted students show that these students are thought to be reached scientific evidence through empirical evidence, they are largely focused on the scientific process and in this context they are more likely to portray male scientists using glasses and laboratory coats using experiment apparatus (Camci-Erdogan, 2013a, 2013b; Turgut, Öztürk and Eş, 2017). In this context, it is necessary that the teachers who work/will work at the elementary school level should be the right role models in terms of perception towards science by the learners and guiding this perception. Because, knowledge, attitudes and values possessed by the learners towards science and scientists are influenced by the knowledge, attitudes and values of their teachers (Altınok, 2004; Palmer, 2001). At this point, being a role model is more important for the teachers - who will work with gifted students who are instinctively curious and motivated to study science and explore - to advance such students' current performance further, to the level of enjoying science. It is essential that teachers whether they work with students who are diagnosed as gifted or not are educated as individuals who are open-minded, inquiry-minded, critical and creative, away from stereotypical thoughts. Therefore, it is necessary for the prospective teachers to directly take courses related to science (such as philosophy of science and history of science) during the undergraduate education. In addition, it is necessary to include critical, creative and evaluative thinking processes about how to distinguish scientific knowledge from pseudoscientific knowledge and how to obtain accurate and reliable scientific resources in the context of these courses. These contents should not only be in a theoretical structure, but also create practical environments where students can criticize scientific knowledge, its source and its presentation and give them opportunity to contemplate the subject and reflect it in the daily life. Teacher candidates must be confronted with the perception towards the scientists they possess and should be heading for thinking about this perception. They should be introduced to the right role models working in different areas of science and be shown that science is in fact very close, that it is not and cannot be isolated from society.

\section{Recommendations}

The present study was carried out as a survey research to determine the perceptions towards scientists and science/pseudoscience distinctions of prospective teachers of gifted education and elementary education who are likely to be teaching to gifted students. It can be suggested for future studies that this study is supported by 
interviews with teacher candidates in terms of both perception towards scientists and decisions regarding the science/pseudoscience distinction, with the hope that the interviews will further the present study.

\section{Acknowledgement}

This study was supported by Scientific Research Projects Coordination Unit of Istanbul University with the project number of 25675 .

\section{References}

Abd-El-Khalick, F., \& Lederman, N. G. (2000). The influence of history of science courses on students' views of nature of science. Journal of Research in Science Teaching, 37(10), 1057- 1095.

Ağlarcı, O., \& Kabapınar, F. (2016). Kimya öğretmen adaylarının bilime ve sözde bilime ilişkin görüşlerinin geliştirilmesi. Amasya Üniversitesi Ĕ̆itim Fakültesi Dergisi, 5(1), 248-286.

Akçay, B. (2011). Turkish elementary and secondary students' views about science and scientist. Asia-Pacific Forum on Science Learning and Teaching, 12(1), 1-11.

Akerson, V. L., Buzzelli, C. A., \& Donelly, L. A. (2010). On the nature of teaching nature of science: Preservice early childhood teachers' instruction in preschool and elementary settings. Journal of Research in Science Teaching, 47(2), 213-233.

Altınok, H. (2004). Öğretmenlerin fen öğretimine yönelik tutumlarına ilişkin öğrenci algıları ve öğrencilerin fen bilgisi dersine yönelik tutum ve güdüleri. Hacettepe Üniversitesi Ĕ̈itim Fakültesi Dergisi, 26, 1-8.

Ayvacı, H. Ş., \& Bă̆, H. (2016). Sınıf öğretmeni adaylarının bilim sözde-bilim ayrımına ilişkin görüşlerinin incelenmesi. Amasya Üniversitesi Ĕ̈itim Fakültesi Dergisi, 5(2), 539-566.

Berkant, H. G., \& Ermeydan, Z. (2017). Eğitim fakültesi öğrencilerinin bilim-sözde bilim ayrımlarının çeşitli değişkenler açısından incelenmesi. Kahramanmaraş Sütçü İmam Üniversitesi Eğitim Dergisi, 1(1), 12-25.

Berkman M. B., Pacheco J. S., \& Plutzer, E. (2008). Evolution and creationism in America's classrooms: A national portrait. PLoS Biol 6(5), 920-924.

Buldu, M. (2006). Young children's perceptions of scientists: A preliminary study. Educational Research. 48(1), 121-132.

Bozdoğan, B., Şengül, Ü., \& Bozdoğan, A.E. (2013). Fen bilgisi öğretmen adaylarının bilim insanları hakkındaki bilgi düzeylerinin incelenmesi: Giresun Eğitim Fakültesi örneği. Karadeniz Sosyal Bilimler Dergisi, 5(9), 227-242.

Camcı, S. (2008). Bilim şenliğine katılan ve katılmayan çocukların bilim ve bilim insanlarına yönelik ilgi ve imajlarının karşılaştırılması. Yayımlanmamış yüksek lisans tezi. Hacettepe Üniversitesi, Ankara.

Camc1-Erdoğan, S. (2013a). Üstün zekâlı kızların bilime yönelik tutumları ve bilim insanı imajları. Hasan Ali Yücel Eğitim Fakültesi Dergisi, 10, 125-142.

Camcı-Erdoğan, S. (2013b). Üstün zekâlı ve yetenekli öğrencilerin bilim insanlarına yönelik algıları. Türk Üstün Zekâ ve Eğitim Dergisi, 3, 13-37.

Camc1- Erdoğan, S., \& Riga, F. (2016). Gifted females in science. In K. S. Taber \& M. Sumida (Eds.), International perspectives on science education for gifted (pp. 106-125). New York: Rotledge.

Camc1-Erdoğan, S. (2018). Üstün zekâlılar öğretmenliği adaylarının gözlerinden bilim insanları. YYÜ Eğitim Fakültesi Dergisi (YYU Journal of Education Faculty), 15(1), 130-155.

Carnes, G. N. (2009). Interpreting drawings of preservice teachers. In J. E. Pederson, \& K. D. Finson (Eds.), Visual data: Understanding and applying visual data to research in education (pp. 79-92). Rotterdam, The Netherlands: Sense.

Chambers, D. W. (1983). Stereotypic images of the scientist: The draw a scientist test. Science Education, 67(2), $255-265$.

Christidou, V. (2011). Interest, attitudes and images related to science: Combining students' voices with the voices of school science, teachers, and popular science. International Journal of Environmental and Science Education, 6(2), 141-159.

Cooper, C. R., Baum, S. M., \& Neu, T. W. (2004). Developing scientific talent in students with special needs. Journal of Secondary Gifted Education, 15(4), 162-169.

Creswell, J. W. (2012). Educational research: Planning, conducting, and evaluating quantitative and qualitative research. Boston, MA: Pearson Education Inc.

Çermik, H. (2013). A scientist created in the picture that pre-service teachers have in their minds. Pamukkale University Journal of Education, 33(1), 139-153. 
Çetinkaya, E., Turgut, H., \& Duru, M. K. (2015). The effect of the context of science, pseudoscience demarcation on the science perceptions of secondary school students: The case of 1ridology. Education and Science, 40(181), 1-18.

Çetinkaya, E. K., Laçin-Şimşek, C., \& Çalışkan, H. (2013). Bilim ve sözde-bilim ayrımı için bir ölçek uyarlama çalışması. Trakya Üniversitesi Ĕ̌itim Fakültesi Dergisi, 3(2), 31-43.

Driver, R., Leach, J., Millar, R., \& Scott, P. (1996). Young people's images of science. Buckingham: Open University Press.

Eret-Orhan, E. \& Ok, A., (2014). Who prefer teacher education programs? Candidates' entry characteristics and attitude towards teaching. Hacettepe University Journal of Education, 29(4), 75-92.

Es, H. \& Turgut, H. (2018). Candidate classroom teachers ${ }^{e e}$ perceptions about being scientific in the context of pseudoscience. Journal of Education in Science, Environment and Health (JESEH), 4(2), 142-154. DOI:10.21891/jeseh.409497

Eve, R.A., \& Dunn, D. (1990). Psychic powers, astrology and creationism in the classroom? Evidence of pseudoscientific beliefs among high school biology and life science teachers. The American Biology Teacher, 52(1), 10-21.

Finson, K., Beaver, J., \& Cramond, B. (1995). Development and field test of a checklist for the draw-a-scientist test. School Science and Mathematics, 95(4), 195-205.

Flick, L. (1990). Scientist in residence program improving children's image of science and scientists. School Science and Mathematics, 90(3), 204-214.

Fort, D. C., \& Varney, H. L. (1989). How students see scientists: Mostly male, mostly white, and mostly benevolent. Science and Children, 26(8), 8-13.

Fung, Y. Y. H. (2002). A comparative study of primary and secondary school students' images of scientists. Research in Science \& Technological Education, 20(2), 199-213.

Gonsoulin, W. B. (2001). How do middle school students depict science and scientist? (Unpublished doctoral dissertation). Mississippi State University, Mississippi.

Hammrich, P. L. (1997, March). Confronting the Gender Gap in Science and Mathematics: The Sisters in Science Program. Paper presented at the Annual Conference of the American Education Research Association. Chicago, USA.

Hewson, P. W., \& Hewson, M. G. A. B. (1989). Analysis and use of a task for identifying conceptions of teaching science. Journal of Education for Teaching, 15(3), 191-209.

Kallery, M. (2001). Early-years educators' attitudes to science and pseudo-science: The case of astronomy and astrology. European Journal of Teacher Education, 24(3), 329-342 .

Karnes, F. A., \& Riley, T. L. (2005). Developing an early passion for science through competitions. In S. K. Johnsen, \& J. Kendrick (Eds.), Science education for gifted students (pp. 25-31). Texas, TX: Prufrock Press.

Kaya, N. O., Doğan, A., \& Öcal, E. (2008). Turkish elementary school students' images of scientists. Eurasian Journal of Educational Research, 32, 83-100.

Kemaneci, G. (2012). Üstün yetenekli ögrencilerin bilim insanı hakkındaki imajlarının araştırılması. (Yayımlanmamış yüksek lisans tezi). Gazi Üniversitesi, Ankara.

Kopelman, M., Galasso, V. G., \& Strom, P. (1977). A model program for the development of creativity in science. Gifted Child Quarterly, 21(1), 80-84.

Lindeman, M. (1998). Motivation, cognition and pseudoscience. Scandinavian Journal of Psychology, 39, 257265.

Lederman, N. G. (1999). Teachers' understanding of the nature of science and classroom practice: Factors that facilitate or impede the relationship. Journal of Research in Science Teaching, 36(8), 916-929.

Lederman, N. G. (2007). Nature of science: Past, present, and future. In S. K. Abell, \& N. G. Lederman (Eds.) Handbook of research on science education (pp. 831-879). New Jersey, NJ: Lawrence Erlbaum Associates.

Losh, S. C., \& Nzekwe, B. (2011). The influence of education major: How diverse preservice teachers view pseudoscience topics. Journal of Science Education and Technology, 20(5), 579-591.

Mahner, M. (2007). Demarcating science from nonscience. In T. A. Kuipers (Ed.), General philosophy of science: Focal issues (pp. 515-576). North Holland: Elsevier.

Matthews, B., \& Davies, D. (1999). Changing children's images of scientists: Can teachers make a difference? School Science Review, 80(293), 79-85.

Mead, M., \& Metraux, R. (1957). Image of the scientist among high-school students. Science, 126 (3270), 384390.

Meador, K. S. (2003). Thinking creatively about science: Suggestions for primary teachers. Gifted Child Today, 26(1), 25-29.

MEB. (2013). İlkögretim kurumları Fen bilimleri dersi (3, 4, 5, 6, 7 ve 8. sinıflar) ögretim programı. Ankara: MEB Yayınevi. 
Milford, T. M., \& Tippett, C. D. (2013). Preservice teachers' images of scientists: Do prior science experiences make a difference? Journal of Science Teacher Education, 24, 745-762.

Moseley, C., \& Norris, D. (1999). Preservice teachers' views of scientists. Science and Children, 37(6), 50-53.

Nehm, R. H., \& Schonfeld, I. S. (2007). Does increasing biology teacher knowledge of evolution and the nature of science lead to greater preference for the teaching of evolution in schools? Journal of Science Teacher Education, 18(5), 699-723.

Ngoi, M., \& Vondracek, M. (2004). Working with gifted science students in a public high school environment. Journal of Secondary Gifted Education, 15(4), 141-147.

Norris, S. P., \& Phillips, L. M. (2003). How literacy in its fundamental sense is central to scientific literacy. Science Education, 87, 224-240.

OECD (2015). Who wants to become a teacher?, PISA in Focus, No. 58, OECD Publishing, Paris, https://doi.org/10.1787/5jrp3qdk2fzp-en.

Oothoudt, B. (2008). Development of an instrument to measure understanding of the nature of science as a process of inquiry in comparison to pseudoscience. (Unpublished master's dissertation). California State University, USA.

Öcal, E. (2007). İlkögrretim 6, 7, 8. Sınıf Öğrencilerinin Bilim İnsanı Hakkındaki İmaj ve Görüşlerinin Belirlenmesi. (Yayınlanmamış Yüksek Lisans Tezi). Gazi üniversitesi, Ankara.

Özkan, B., Özeke, V., Güler, G., \& Şenocak, E. (2017). Üniversite öğrencilerinin bilim insanı imajları ve bu imajları etkileyen bazı faktörler. Erzincan Üniversitesi Eğitim Fakültesi Dergisi, 19(1), 146-165.

Palmer, D. H. (2001). Factors contrubuting to attitude exchange amongs preservice elementary teachers. Science Education, 86, 122-138.

Preece, P. F., \& Baxter, J. H. (2000). Scepticism and gullibility: The superstitious and pseudo-scientific beliefs of secondary school students. International Journal of Science Education, 22(11), 1147-1156.

Reap, M. A., Cavallo, A. M. L., \& McWhirter, L. J. (1994, January). Changing perceptions of scientists among preservice elementary school teachers. Paper presented at the Annual International Conference of the Association for the Education of Teachers in Science. El Paso, TX.

Saka, M., \& Sürmeli, H. (2017). Fen bilgisi öğretmen adaylarının sözde bilimsel senaryolarda bilimin doğasını kullanımı. Trakya Üniversitesi Eğitim Fakültesi Dergisi, 7(2), 504-525.

Schibeci, R. (2006). Student images of scientists: What are they? Do they matter? Teaching Science, 52(2), 1216.

She, C. H., \& Fisher, D. (2002). Teacher communication behavior and its association with students' cognitive and attitudinal outcomes in science in Taiwan. Journal of Research in Science Teaching, 39(1), 63-78.

Smith, M. U., \& Scharman, L. C. (1999). Defining versus Describing the Nature of Science: A Pragmatic Analysis for Classroom Teachers and Science Educators. Science Education, 83(4), 493-509.

Smutny, J., \& Von Fremd, S. E. (2004). Differentiating for the young child. Thousand Oaks, CA: Corwin Press.

Song, J., \& Kim, K. (1999) How Korean students see scientists: The images of the scientist. International Journal of Science Education, 21(9), 957-977.

Sönmez, S. (2007). Preschool teachers' attitudes toward science and science teaching. (Unpublished doctoral dissertation). Middle East Technical University, Ankara.

Suchting, W. A. (1995). The nature of scientific thought. Science \& Education, 4, 1-22.

Symington, D., \& Spurling, H. (1990). The 'Draw a Scientist Test': Interpreting the data. Research in Science \& Technological Education, 8(1), 75-77.

Şenel, T., \& Aslan, O. (2014). Okulöncesi öğretmen adaylarının bilim ve bilim insanı kavramlarına ilişkin metaforik algıları. Mersin Üniversitesi Eğitim Fakültesi Dergisi, 10(2), 76-95.

Şenler, B., \& İrven, Ö. (2016). Sınıf öğretmeni adaylarının epistemolojik inançları ile sözde-bilimsel inançları. Mersin Üniversitesi Ë̆itim Fakültesi Dergisi, 12(2), 659-671.

Taber, K. S. (2007). Science education for gifted learners?. In K. S. Taber (Ed.), Science education for gifted learners (pp. 1-14). New York, NY: Routledge.

Turgut, H. (2007). Herkes için bilimsel okuryazarlık. Ankara Üniversitesi Eğitim Bilimleri Fakültesi Dergisi, 40(2), 233-256.

Turgut, H. (2009). Fen ve teknoloji öğretmen adaylarının bilimsel, sözde-bilimsel ayrımına yönelik algıları. Ĕ̈itim ve Bilim, 34(154), 50-68.

Turgut, H. (2011). The context of demarcation in nature of science teaching: The case of astrology. Science \& Education, 20, 491-515.

Turgut, H., Akçay, H., \& İrez, S. (2010). The impact of the issue of demarcation on pre-service teachers' beliefs on the nature of science. Educational Sciences: Theory and Practice, 10(4), 2621-2663.

Turgut, H., Eş, H., Bozkurt-Altan, E., \& Öztürk-Geren, N. (2016). Okul öncesi öğretmen adaylarının, bilim, sözde-bilim algıları. International Online Journal of Educational Sciences, 8(1), 150-169.

Turgut, H., Öztürk, N., \& Eş, H. (2017). Üstün zekâlı öğrencilerin bilim ve bilim insanı algısı. Abant İzzet Baysal Üniversitesi Ë̆itim Fakültesi Dergisi, 17(1), 423-440. 
Türkmen, H. (2008). Turkish primary students' perceptions about scientist and what factors affecting the image of scientists. Eurasia Journal of Mathematics, Science \&Technology Education, 4(1), 55-61.

Ünver, A. O. (2010). Perceptions of scientists: A comparative study of fifth graders and fourth year student teachers. Necatibey Faculty of Education Electronic Journal of Science and Mathematics Education, 4(1), 11-28.

Ürey, M., Karaçöp, A., Göksu, V., \& Çolak, K. (2017). Fen ve sosyal bilimler kökenli öğretmen adaylarının bilim insanı algıları. YYÜ Ĕ̈itim Fakültesi Dergisi, 14(1), 205-226.

Washton, E. S. (1971). Improving elementary teacher education in science. New York, NY: Macmillan.

Yates, C. R., \& Chandler, M. (2000). Where have all the skeptics gone? Patterns of new age beliefs and antiscientific attitudes in preservice primary teachers. Research in Science Education, 30, 377-387.

Yıldırım, A., \& Şimşek, H. (2008). Sosyal bilimlerde nitel araştırma yöntemleri. Ankara: Seçkin Yayınları

Yıldırım, C. (2008). Bilimsel düşünme yöntemi (2. Baskı). Ankara: İmge Yayınevi.

Y1ldırım, C. (2010). Bilim felsefesi (13. Baskı). İstanbul: Remzi Kitabevi.

Yontar-Toğrol, A. (2000). Öğrencilerin bilim insanı ile ilgili imgeleri. Eğitim ve Bilim, 25(118), 49-57.

\section{Author Information}

Sezen Camci Erdogan

Istanbul University-Cerrahpasa

Hasan Ali Yucel Faculty of Education, Istanbul, Turkey

Contact e-mail: scamci@istanbul.edu.tr 